\title{
INHALT
}

\section{J. EGERT}

Die Messung des elektrischen Widerstandes des Blattgewebes zur indirekten Bestimmung des Wasserzustandes bei der Apfelsorte 'Carola'

\section{S. SCHMIDT}

Nukleinsäuremetabolısmus und Blütenknospenentwicklung bei Apfel (Malus domestica)

G. Stolle, B. Herold, G. Schmint

Die Messung mechanischer Belastungen von Äpfeln bei Ernte und Transport durch telemetrische MeBkörper

M. VogL, H. MutTELSTÄDT

Frostschutz im Obstbau - Möglichkeiten in Gegenwart und Zukunft .

\section{СОДЕРЖКАНIIE}

E. ЭГЕРт

Измерение электрического conpoтивления ткани листа для косвепного определения водного режима у сорта яблони 'Карола' . . . . . . 169

\section{С. Шмидт}

Обмен нуклепновых кислот и развитие цветочных почек у яблони (Malus dumestica) . . . . . . . .
Г. ШтоллЕ, Б. Хғрольд, Г. ІШмидт

Измерение механических нагрузок на яболоки при уборке урежая и транспортировке с помощью шарового радиотелеметрического датчика давления . . . . . . . . . . .

169 М. Фогль, Х. Миттельштәдт

Защита от морозов в плодоводстве - возможности в настоящее время и в будущем . . . . . . . . . . . 199

\section{CONTENTS}

\section{J. EGERT}

IIeasurement of electrical resistance in leaf tissue for indirect determination of water balance in 'Carola' apple. . . . . . . . . . 169

S. SCHMIDT

Nucleic acid metabolısm ant flower bud development in apple (Malus domestica) . . . . . . . . . . 177

G. Stolle, B. Herold, G. Schmidt

Telemetric measuring device for recording mechanical stress on apple during harvest and transport . . . 189

M. Vogl, H. MittéLstäDT

Prevention of frost damage in fruit growing - present and future possi177: bilitıes . . . . . . . . . 199 

